\title{
EFFECT OF GENDER GAP IN EDUCATION ON DISTRICT LEVEL GDP PER CAPITA OF NEPAL
}

\author{
Madhav Prasad Dahal*
}

\begin{abstract}
Growth theories developed in the 1980s and 1990s incorporate education centered human capital to explain the cross-country and country specific variations in the per capita gross domestic product. This article examines the effect of gender inequality in education on the per capita GDP of the districts of Nepal. Gender inequality in education is more pronounced in less developed countries than in developed countries. Utilizing the data pertaining to the year 2001 taken from Nepal Human Development Report 2004 published by United Nations Development Program (UNDP) country office Nepal, we find that gender gap in education has obvious negative impact on district level GDP per capita of Nepal. This bears implication in policy formulation to minimize the gender disparity in education.
\end{abstract}

Key words: GDP per capita, human capital, educational gender gap, cross-district data, Nepal

\section{INTRODUCTION}

The birth of endogenous growth theory in the 1980s and the formalization of human capital augmented Solow's growth model by Mankiw, Romer and Weil (1992) opened the venue for incorporating education-centered human capital in cross-country and country specific growth studies. In the 1990s the trend of studying the effect of gender separate education and gender disparity in education on gross domestic product (GDP) per capita and its growth also emerged in the academic field. Views of scholars converge on the line of reasoning that countries with higher levels of women's education experience more rapid economic growth, longer life expectancy, lower population growth, and improved quality of life, and there is an especially high rate of return from investments in girls' education in developing countries. Summers (1992) observed that investment in the education of girls and women has a higher return than any other investment in physical or human capital because educated women confer sizeable tangible benefits on their families and communities. Each additional year of a girl's education increases her subsequent income; it also reduces female fertility, cuts maternal mortality, and improves the health of a woman's children. It is further added that enhancing women's contribution to development is both an economic and social issue. Summers concludes that the return on investment in girls' education is well over

\footnotetext{
* Mr. Dahal is Associate Professor of Economics, Tribhuvan University, Patan Multiple Campus.

Email: md_macro@hotmail.com; mdmacro@yahoo.com
} 
20 per cent. These realities have attracted the attention of economists to analyze the economic contribution of female's education.

In Nepal educational opportunities are undoubtedly being expanded but there is apparent disparity in the educational attainment of the male and female population. The educational attainment of the male population is higher than that of the female population. For example, as per Nepal Human Development Report 2004 published by UNDP Nepal (UNDP, 2004), the mean years of schooling of female in the year 2001 was 1.95 years and that of the male population was 3.56 years, and as per Nepal Human Development Report 2009 published by UNDP Nepal (UNDP, 2009) the mean years of schooling of female in year 2006 was 2.468 years and 4.080 years for the male. The main objective of the present paper is to investigate empirically the impact of educational gender gap on the district level GDP per capita of Nepal.

The structure of the rest of the paper is as follows. The next section presents review of previous empirical works on the effect of gender inequality in education growth. The third section discusses the research methodology; the fourth discusses the empirical results and the final section offers conclusive comments.

\section{LITERATURE RETROSPECTION}

A number of papers on cross-country growth study have affirmed the significance of female education. There are two types of macro level studies investigating the relation between gender separate education and economic growth: studies that simply consider the effect of gender-separate education on growth and studies that ponder the impact of educational gender gaps (inequality) on growth. We briefly visit the later category of literature.

Possibly Hill and King (1995) were the first to deal with the educational gender gap issue with the main emphasis on whether this gap hindered economic growth and productivity, and affected indicators of social well-being like fertility, infant mortality and life expectancy. They measured gender gap in education as a ratio of female to male enrolments at the primary or secondary level, whichever was the larger. Hill and King employed a recursive approach for estimation on the pooled time-series data of five-year periods from 1960 to 1985.The empirical result of Hill and King indicated a significant positive impact of the level of female education on the level of gross national product (GNP) but a growth retarding effect of large gender disparities in educational attainment. It is calculated that for a given level of female education, labor force and capital stock, a country with a large gender gap in education is likely to have income that is $25 \%$ lower than a country with a smaller gender gap. The major conclusion of the study is that as female education and the educational gender gap are important determinants of both economic growth and family well-being, the failure to improve female education to the same or higher average level of males will act as a brake on development. 
By considering both enrollment rates and literacy rate together Sadeghi (1995) investigated the effect of educational gender gap on the growth of per capita gross national product (GNP) in cross-country data set of the period 1950-1989. The sample consisted of 93 countries selected from non-European members of Organization of Petroleum Exporting Countries (OPEC) and from the East Asian region. Gender gap in education is measured by the ratio of female to male literacy and the ratio of female to male enrollment. Linear and linear-log regression models were estimated by applying the method of ordinary least square (OLS) regression. The study found positive and statistically significant coefficients of educational gender gap which implied that reduction in gender gap in education would positively contribute on economic growth.

The studies prior to Dollar and Gatti (1999) in the subject matter of gender inequality, income and growth, did not explicitly investigate the specific issues like: (a) Is lower investment in girls' education simply an efficient economic choice for developing countries? (b)Does gender inequality reflect different social or cultural preferences about gender roles? (c) Is there evidence of market failures that may lead to underinvestment in girls, failures that may decline as countries develop? These issues were empirically handled by Dollar and Gatti by using cross-country panel data consisting of up to 127 countries for periods of 1975-79 to 1990.The study focussed on four indicators of gender inequality :(i) access and achievement in education (especially secondary level educational attainment);(ii) improvement in health measured by gender-disaggregated life expectancy; (iii) indexes of legal and economic equality of women in society and marriage; and (iv) measures of women's empowerment (percentage of women in parliament, year when women earned the right to vote). In the study gender inequality in education is measured as female secondary attainment minus male secondary attainment. Treating gender inequality as an endogenous variable, it is hypothesized that gender inequality is a function of per capita income, religious preference, regional factors, and civil liberties or economic policy. The major findings of the study of Dollar and Gatti are directed towards three issues: influence of religion on gender inequality; effect of educational gender disparity on economic growth; and effect of improved income on gender equality. As regard to the finding relating to gender inequality and economic growth, the result showed substantial adverse effect of gender inequality in education on economic growth as indicated by the significantly negative coefficient of gender inequality variable. In the case of more developed countries the study found a significant positive coefficient of female's secondary educational attainment and an insignificant negative coefficient of male's educational attainment, a result opposite to the findings of Barro and Lee (1994) who reported negative coefficient of female education and positive coefficient of male education. For the full sample of countries Dollar and Gatti found a weak negative coefficient on male education and a weak positive coefficient on female education for which the use of dummy variable is held accountable. The basic message that emerged from the analysis is that gender equality and economic development are mutually 
reinforcing. So investment in female education would lead to the increase in national income, which in turn would lead to more gender equality in education and in other areas.

Differing with earlier studies in terms of the measure of human capital (e.g., total years of schooling, female-male ratio of total years of schooling, annual growth in total years of schooling) and handling the multicollinearity problem, Klasen (1999) investigated the extent to which gender inequality in education and employment could reduce growth and development. Taking cross-country data of the period between 1960 and 1990, this study purposely focused on the direct effects of educational gender bias on growth, and any indirect effects that it may have on investment, population and labor force growths. The study applied the ordinary least square (OLS) method on multivariate regression equations. As in the findings of previous studies gender inequality in education slowed down economic growth directly by distorting incentives and indirectly through its impact on investment and population growth. Klasen claims that if South Asia and Sub-Saharan Africa had achieved themselves with more balanced educational achievements in 1960, and they had done more to promote gender-balanced growth in education, their economic growth could have been up to $0.9 \%$ per year faster than it turned out to be the case. Point estimates suggested that between $0.4-0.9 \%$ of the differences in growth rates between East Asia and Sub-Saharan Africa, South Asia, and the Middle East could be accounted for by the larger gender gaps in education prevailing in the latter regions. Klasen concludes by supporting the view that policies promoting gender equity in education and employment would represent one of the few "win-win" strategies, in view of the fact that they would foster economic prosperity and efficiency, promote other critical human development goals like lower mortality and fertility.

The empirical study made by Knowles, Lorgelly and Owen (2002) attempts to resolve many of the shortcomings of the previous empirical work on gender separate education and economic growth. The study expresses concerns on the possibly biased estimates in earlier cross-sectional growth literature mainly due to the likely correlation of country-specific error terms with the explanatory variables. The core theoretical framework of Knowles, Lorgelly and Owen is a constant return to scale Cobb-Douglas production function in the style of Mankiw, Romer and Weil (1992) within the vein of neoclassical growth model. In the analytical framework real output $(Y)$ of each country at a particular time is made a function of the stock of real physical capital (K), the stock of female education (EF), the stock of male education (EM), the stock of health $\operatorname{capital}(\mathrm{X})$, the level of technology $(\mathrm{A})$, and the labor force $(\mathrm{L})$. This functional form also allowed them to interpret the coefficients explicitly and it also enabled them to reparameterize the model by including a gender gap variable (defined as the stock 
of male education minus the stock of female education), in a fashion similar to Hill and King (1995). In numerous versions of their model (they add additional control variables, take account of outliers and influential observations),Knowles, Lorgelly and Owen found the coefficient on female education significantly positive while the coefficient for male education was not significantly different from zero (although it is negative and significant in some of the two stage least squares estimations).The implication of this finding is that countries with higher levels of female schooling will have higher levels of labor productivity, ceteris paribus. The ordinary least squares (OLS) estimate made by entering life expectancy variable renders all variables except life expectancy statistically insignificant. The estimate made by including technical efficiency variable reduces the significance of the life expectancy variable at $10 \%$ level and improves the significantly positive coefficient of female education. Even in the estimates made by including the sample of least developed countries (LDCs) only, the female education variable remains positively significant while the male education variable is significantly negative. In the reparameterized version of the model, the coefficients of female and male education variables are statistically alike to the earlier estimates but the coefficient of education gender gap variable (EM-EF) is negative and statistically significant. Thus the findings of Knowles, Lorgelly and Owen on the role of female education are similar to the findings of Hill and King (1995), Dollar and Gatti (1999) and Klasen (1999) but opposite to Barro and Lee (1994).

By extending and replicating Klasen's (1999) analysis from 1960- 1990 to 1960-2000, Klasen and Lamanna (2009) re-confirm the strong growth retarding effect of gender gaps in education and employment applying panel growth regressions pioneered by Barro (1991).They used the male education level as a proxy for average education as an upper-bound estimate for the effect of gender inequality in education on economic growth, with the implicit assumption that one could improve the gender gap in education by sending more girls to school without having to take out boys (and in this way the male education level is held constant). They employed the ordinary least squares (OLS) method to estimate a system of several equations. The result showed that growth impeding effect of gender inequality in employment was larger than the effect of gender inequality in education. Once Sub-Saharan Africa and Latin America in the1990s were excluded from the estimation, education and employment gaps had a similar impact on economic growth. The study estimated that the combined 'costs' of education and employment gaps in the Middle East and North Africa, and South Asia amounted respectively to 0.9-1.7 and 0.1-1.6 percentage point differences in growth compared to East Asia. The conclusion of the study is that the challenge of increasing the economic growth of a country, to a considerable extent, is linked to the role played by women in the society and the discrimination to women in education and employment harms not only women but also imposes a cost to the entire society. 
Therefore the study suggested that nations should reduce existing gender inequality in education and employment so as to promote growth and support the achievement of other valuable development goals.

Thus there have been cross country studies assessing the impact of gender gap in education on the GDP per capita of nations but such studies have been lacking in Nepal. The present papers contribute in filling this gap.

\section{RESEARCH METHODOLOGY}

\section{Theoretical Premise, Model Specification and Estimation}

The theoretical foundation for the inclusion of education in explaining district level per capita GDP of Nepal in this paper is the human capital theory developed by Schultz (1960, 1961), Mincer $(1958,1974)$, Becker $(1962,1975)$ and the emphasis of educationcentered human capital in the endogenous growth theories pioneered by Lucas (1988) and Romer(1990).Depending upon these scholarly works we hypothesize that human capital measured by the overall and gender separate average years of schooling has positive effect on district level per capita GDP of Nepal; and drawing upon the empirical works reviewed earlier we hypothesize that gender gap in education has negative effect on the district level GDP per capita of Nepal. The core theoretical framework of the present study is a Cobb-Douglas production function in the style of Mankiw, Romer and Weil (1992) and Knowles, Lorgelly and Owen (2002) which are primarily in the tradition of neoclassical growth model. The function is specified as:

$$
Y_{i t}=A K_{i t}^{\alpha} E_{i t}^{\beta_{f}} \operatorname{EM}_{i t}^{\beta_{m}}\left(L_{i t}\right)^{1-\alpha-\beta_{f}-\beta_{m}}
$$

where $\mathrm{Y}$ is real output, $\mathrm{K}$ is the stock of real physical capital proxied by total land holding, EF is the stock of female education, EM is the stock of male education, A is the level of technology(a measure of ignorance), and $L$ is the labor force. Subscripts $i$ and $t$ denote district $i$ and time period $t$ respectively $\beta_{\mathrm{f}}$ and $\beta_{\mathrm{m}}$ are response parameters related to female and male education. The Cobb-Douglas production function exhibits constant returns to scale, and the marginal products of each factor are assumed to be positive and diminishing. In the production function stock of female and male education variables are entered as separate inputs along with land capital stock (K) and labor force (L). In per capita form equation (1) can be written as:

$$
\mathrm{y}_{\mathrm{it}}=\mathrm{Ak}_{\mathrm{it}}^{\alpha} \mathrm{ef}_{\mathrm{it}}^{\beta_{\mathrm{f}}} \mathrm{em}_{\mathrm{it}}^{\beta_{\mathrm{m}}}
$$

where the lower case letters denote quantities per unit of labor. 
The per capita production function is estimated by including the educational gender gap variable (INEQU) which is the ratio of the logarithmic value of female mean years of schooling to the logarithmic value of male mean years of schooling. In estimation the logarithmic values of $\mathrm{Y}, \mathrm{K}, \mathrm{EF}$ and EM are used. The method of ordinary least square (OLS) is employed to estimate all equations. Entire statistical work is performed in Eviews Software version 4.

\section{Data}

The data on district level gross domestic product (GDP), district level population, overall mean years of schooling and gender separate mean years of schooling come from Nepal Human Development Report (NHDR) 2004 published by United nations Development Program (UNDP, 2004) country office Nepal and the data pertain to the year 2001.The data on the size of land holding are taken from Statistical Year Book of Nepal 2007 published by the Central Bureau of Statistics(CBS,2008) of the Government of Nepal. There are altogether 75 data points in the empirical estimates, each observation relating to each of the 75 geographical districts of Nepal.

\section{EMPIRICAL RESULTS AND DISCUSSION}

The empirical results are discussed with the aid of Table 1 . Three regression equations are estimated in which the dependent variable is district level GDP per capita of Nepal. We first looked at the relation of district level per capita GDP with male mean years of schooling, female mean years of schooling, land capital stock and educational gender gap. Then we estimated the effect of gender inequality in education along with the overall human capital stock measured by mean years of schooling $(\mathrm{H})$ and land capital stock. The empirical result reveals that gender inequality in education (INEQU) in Nepal has obvious negative effect on the district level GDP per capita of the country. Out of the three cases the negative coefficient of the 'INEQU' variable is highly significant in two cases. The negative coefficient in two of the cases exceeds one which indicates more than one percentage point decease in the district level GDP per capita due to one percentage point increase in educational gender gap. The result corresponding to Model 1 and model 2 also reveals the significant contribution of female education in the economic wellbeing of Nepal. These findings on the negative effect of educational gender gap are similar to the findings of Hill and King (1995), Dollar and Gatti (1999), Klasen (1999), Knowles, Lorgelly and Owen (2002) and Klasen and Lamanna (2009). 
Table 1: Effect of Educational Gender Gap on Per Capita GDP

\begin{tabular}{|c|c|c|c|c|c|}
\hline Model 1 & Variables & Coefficient & Std. Error & $\mathrm{t}$-Statistic & Prob. \\
\hline & $\mathrm{C}$ & 4.318083 & 0.885182 & 4.878184 & 0.0000 \\
\hline & $\ln K$ & 0.445146 & 0.075262 & 5.914607 & 0.0000 \\
\hline & $\ln E F$ & 1.306474 & 0.372722 & 3.505220 & 0.0008 \\
\hline & INEQU & -1.137146 & 0.444223 & -2.559854 & 0.0126 \\
\hline & Adjusted R-squared & 0.403364 & \multicolumn{2}{|c|}{ S.D. dependent var } & 0.563153 \\
\hline & S.E. of regression & 0.434992 & \multicolumn{2}{|c|}{ Akaike info criterion } & 1.224879 \\
\hline & Sum squared resid & 13.43446 & \multicolumn{2}{|c|}{ Schwarz criterion } & 1.348478 \\
\hline & Log likelihood & -41.93295 & \multicolumn{2}{|l|}{ F-statistic } & 17.67625 \\
\hline & Durbin-Watson stat & 1.951273 & \multicolumn{2}{|c|}{ Prob(F-statistic) } & 0.000000 \\
\hline \multirow[t]{11}{*}{ Model 2} & Variables & Coefficient & Std. Error & t-Statistic & Prob. \\
\hline & $\mathrm{C}$ & 4.308813 & 1.093486 & 3.940438 & 0.0002 \\
\hline & $\ln K$ & 0.445271 & 0.076274 & 5.837804 & 0.0000 \\
\hline & $\ln E F$ & 1.298759 & 0.647017 & 2.007303 & 0.0486 \\
\hline & $\operatorname{lnEM}$ & 0.007976 & 0.544849 & 0.014640 & 0.9884 \\
\hline & INEQU & -1.131278 & 0.600672 & -1.883355 & 0.0638 \\
\hline & Adjusted R-squared & 0.394843 & \multicolumn{2}{|c|}{ S.D. dependent var } & 0.563153 \\
\hline & S.E. of regression & 0.438087 & \multicolumn{2}{|c|}{ Akaike info criterion } & 1.251542 \\
\hline & Sum squared resid & 13.43442 & \multicolumn{2}{|c|}{ Schwarz criterion } & 1.406041 \\
\hline & Log likelihood & -41.93283 & \multicolumn{2}{|l|}{ F-statistic } & 13.07056 \\
\hline & Durbin-Watson stat & 1.951305 & \multicolumn{2}{|c|}{ Prob(F-statistic) } & 0.000000 \\
\hline \multirow[t]{10}{*}{ Model 3} & Variables & Coefficient & Std. Error & $\mathrm{t}$-Statistic & Prob. \\
\hline & $\mathrm{C}$ & 3.704297 & 0.966377 & 3.833181 & 0.0003 \\
\hline & $\ln K$ & 0.445523 & 0.076730 & 5.806356 & 0.0000 \\
\hline & $\ln \mathrm{H}$ & 1.015040 & 0.325786 & 3.115666 & 0.0026 \\
\hline & INEQU & -0.231542 & 0.224857 & -1.029730 & 0.3066 \\
\hline & Adjusted R-squared & 0.384297 & \multicolumn{2}{|c|}{ S.D. dependent var } & 0.563153 \\
\hline & S.E. of regression & 0.441888 & \multicolumn{2}{|c|}{ Akaike info criterion } & 1.256336 \\
\hline & Sum squared resid & 13.86379 & \multicolumn{2}{|c|}{ Schwarz criterion } & 1.379935 \\
\hline & Log likelihood & -43.11260 & \multicolumn{2}{|l|}{ F-statistic } & 16.39595 \\
\hline & Durbin-Watson stat & 1.924907 & \multicolumn{2}{|c|}{ Prob(F-statistic) } & 0.000000 \\
\hline
\end{tabular}

Source: Author's estimation. 
In the estimate made by including average human capital measured by the overall mean years of schooling or the average human capital $(\mathrm{H})$ the statistical significance of the negative effect of educational inequality variable is lost as indicated by Model 3 even though the coefficient of the inequality variable continues to be negative. The average human capital or average years of schooling which combines both male and female population should have absorbed the significance of the negative effect of educational gender gap variable. The findings on the statistically significant positive coefficient of human capital variable measured by average years of schooling supports the endogenous growth theory of Lucas (1988) and the human capital augmented Solow's model of Mankiw, Romer and Weil (1992).This highlights the importance of education-centered human capital in bringing higher GDP of economies

The positive and statistically significant coefficient of the land capital stock variable (K) indicates the crucial important of land resources in the production of the GDP of each district of Nepal. The statistical significance of each of the model is satisfactory as indicated by the significant F-statistic.

\section{CONCLUSION}

The study empirically estimated the effect of female education, education-centered human capital and educational gender gap on the district level GDP per capita of Nepal. The result indicated that education-centered human capital has significant positive impact on the GDP per capita of each of the districts of Nepal. In this regard the role of female education is rather crucial. However the apparent disparity in education between male and female is detrimental for the economic well being of Nepal. Hence the policy prescription is that Nepal should enhance the education level of its labor force and reduce the educational gender gap between male and female; females are to be more encouraged to attain education.

\section{References}

Barro, R J. (1991). Economic growth in a cross section of countries. Quarterly Journal of Economics, 106, 407-443.

Barro, R. J.,\& Lee, J.-W. (1994). Sources of economic growth. Carnegie-Rochester Conference Series on Public Policy, 40, 1-46

Becker, G. S. (1962). Investment in human beings. The Journal of Political Economy 70, Part 2, 9-49

Becker, G. S. (1964). Human Capital, 1st Ed. New York: Columbia University Press for the National Bureau of Economic Research.

Central Bureau of Statistics (CBS, 2008). Statistical year book of Nepal 2007. Kathmandu: Author

Dollar, D., \& Gatti, R. (1999). Gender Inequality, Income, and Growth: Are Good Times Good for Women? Policy Research Report On Gender and Development Working Paper Series, 
No. 1.Development Research Group/ Poverty Reduction and Economic Management Network, Washington D.C.: The World Bank

Hill, M. A., \& King, E. M. (1995). Women's education and economic well-being. Feminist Economics, 1(2), 21-46.

Klasen, S. (1999). Does Gender Inequality Reduce Growth and Development? Evidence from CrossCountry Regressions. Policy Research Report On Gender and Development Working Paper Series, No. 7. Development Research Group/ Poverty Reduction and Economic Management Network, The World Bank

Klasen, S., \& Lamanna, F. (2009). The impact of gender inequality in education and employment on economic growth: New evidence for a panel of countries. Feminist Economics, 15(3), 91-132. DOI: 10.1080/13545700902893106

Knowles, S., Lorgelly, P. K., \& Owen, P. D. (2002). Are educational gender gaps a brake on economic development? Some cross-country empirical evidence. Oxford Economic Papers, 54, 118-149

Lucas, R.E., Jr. (1988). On the mechanics of economic development. Journal of Monetary Economics, $22,3-42$

Mankiw, N.G., Romer, D., \& Weil, D. N. (1992). A contribution to the empirics of economic growth. Quarterly Journal of Economics, 107, 407-437.

Mincer, J. (1958). Investment in human capital and personal income distribution. The Journal of Political Economy, 66, 281-302

Mincer, J. (1974).Schooling, experience, and earnings. New York: National Bureau of Economic Research

Romer, P. M. (1990).Human capital and growth: theory and evidence. Carnegie-Rochester Conference Series on Public Policy, 32, 251-286

Sadeghi, J. M. (1995). The relationship of gender difference in education to economic growth: a crosscountry analysis. Economic Research Forum for the Arab Countries, Iran and Turkey (ERF) Working Paper no. 9521. Retrieved February 14, 2011, from http://idl-bnc.idrc.ca

Schultz, T.W. (1960). Capital formation by education. The Journal of Political Economy, 68, 571583

Schultz, T. W. (1961). Investment in human capital. The American Economic Review, 51, 1-17

Summers, L. (1992). Investing in all the people. Policy Research Working Paper Series 905. Washington, D.C.: The World Bank

United Nations Development Program (UNDP, 2004). Nepal human development report 2004. Kathmandu: Author

United Nations Development Program (UNDP, 2009). Nepal human development report 2009. Kathmandu: Author. 